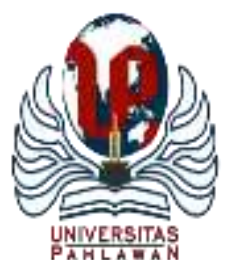

Edukatif : Jurnal Ilmu Pendidikan Volume 3 Nomor 6 Tahun 2021 Halm 4731 - 4737 EDUKATIF: JURNAL ILMU PENDIDIKAN

Research \& Learning in Education

https://edukatif.org/index.php/edukatif/index

\title{
Efektivitas Pembelajaran Online di Masa Pandemi Covid-19
}

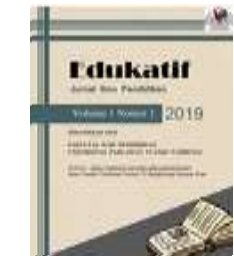

\author{
Rini Sefriani ${ }^{1 凶}$, Rina Sepriana ${ }^{2}$, Indra Wijaya ${ }^{3}$, Menrisal $^{4}$
}

Universitas Putra Indonesia Yptk Padang, Indonesia ${ }^{1,2,3,4}$

E-mail : rinisefriani@upiyptk.ac.id ${ }^{1}$, rinasepriana3@ gmail.com²

\begin{abstract}
Abstrak
Pemberlakuan pembelajaran online oleh pemerintah Indonesia melalui kebijakan Kementrian pendidikan dan kebudayaan riset dan teknologi terhadap semua instansi pendidikan baik formal maupun nonformal, telah membuka celah baru dalam pelaksanaan sistem pembelajaran. Penelitian ini bertujuann untuk mengetahui efektivitas pembelajaran online di tingkat perguruan tinggi mahasiswa Jurusan Pendidikan Teknik Informatika Universitas Putra Indonesia Yptk Padang. Jenis penelitian ini adalah Kuantitatif dengan pendekatan eksperimen semu dengan melihat perbandingan nilai hasil pembelajaran online. Sampel dalam penelitian ini berjumlah tiga puluh tiga orang mahasiswa yang terdaftar dalam perkuliahann fisika terapan.Teknik pengambilan sampel yaitu purposive sampling dan instrumen yang digunakan berupa soal ujian. Hasil penelitian menunjukkan bahwa pembelajaran online dengan menggunakan learning managements system (LMS) Edmodo memberikan dampak yang lebih baik terhadap nilai pembelajaran fisika terapan mahasiswa, yang dibuktikan dengan nilai $\mathrm{N}$-gain yang diperoleh yaitu skor $\mathrm{N}$-gain sebesar 0,25yang bermakna efektif pembelajaran online dilakukan dengan memanfaatkan Learning Managements System Edmodo pada perkuliahann secara online mata kuliah fisika terapan. Maka dapat disimpulkan bahwa LMS sangat mendukung pembelajaran online di tingkat perguruan tinggi yang dapat mengoptimalkan pembelajaran online di masa pandemik Covid 19.
\end{abstract}

Kata Kunci: efektivitas, Pembelajaran online, Covid-19.

\begin{abstract}
The implementation of online learning by the Indonesian government through the policies of the Ministry of Education and Culture, Research and Technology towards all educational institutions, both formal and non-formal, has opened a new gap in the implementation of the learning system.. This study aims to determine the effectiveness of online learning at the university level for students of the Department of Information Engineering, Universitas Putra Indonesia, Yptk Padang. This type of research is quantitative with a quasi-experimental approach by looking at the comparison of the value of online learning outcomes. The sample in this study amounted to thirty-three students who were enrolled in applied physics lectures. The sampling technique was purposive sampling, and the instrument used is in the form of exam questionsThe results showed that online learning using Edmodo's learning management system (LMS) had a better impact on students' applied physics learning scores, as evidenced by the $N$-gain value obtained, namely the N-gain score of 0.25 which means that online learning is effective using utilizing Edmodo's Learning Managements System in online lectures for applied physics courses. So it can be concluded that LMS really supports online learning at the university level which can optimize online learning during the COVID-19 pandemic.
\end{abstract}

Keywords: effectiveness, online learning, covid-19.

Copyright (c) 2021 Rini Sefriani, Rina Sepriana, Indra Wijaya, Menrisal

$\triangle$ Corresponding author

Email : rinisefriani@upiyptk.ac.id

DOI : https://doi.org/10.31004/edukatif.v3i6.1430

ISSN 2656-8063 (Media Cetak)

ISSN 2656-8071 (Media Online)

Edukatif : Jurnal Ilmu Pendidikan Vol 3 No 6 Tahun 2021 p-ISSN 2656-8063 e-ISSN 2656-8071 
4732 Efektivitas Pembelajaran Online di Masa Pandemi Covid-19 - Rini Sefriani, Rina Sepriana, Indra Wijaya, Menrisal

DOI: https://doi.org/10.31004/edukatif.v3i6.1430

\section{PENDAHULUAN}

Pemberlakuan pembelajaran online oleh pemerintah Indonesia melalui kebijakan Kementrian Pendidikan dan Kebudayaan Riset dan Teknologi terhadap semua instansi pendidikan baik formal maupun nonformal, telah membuka celah baru dalam pelaksanaan sistem pembelajaran. Awal Maret 2020 pemerintah Indonesia memberlakuan kebijakan kegiatan di luar rumah dengan mengalihkannya di rumah saja. Baik itu kegiatan instansi pemerintahan, perkantoran, perusahaan dan kegiatan di instansi pendidikan. Pemerintah berupaya untuk mencegah terjadinya penularan virus Covid-19 dengan menerapkan dan menganjurkan kerja dari rumah, belajar dari rumah, menjaga jarak, memakai masker dan sering mencuci tangan. (Firman, F., \& Rahayu, n.d.) menyatakan bahwa pembelajaran online mendorong munculnya perilaku social distancing dan dapat meminimalisir munculnya keramaian mahasiswa sehingga diasumsikan mampu mengurangi potensi penyebaran Covid-19. Hal ini terkait juga di tingkat pendidikan tinggi dengan melaksanakan pembelajaran dari rumah yang biasa di istilahkan dengan belajar dalam jaringan atau daring dan sering juga disebut dengan pembelajaran online. Pelaksanaan pembelajaran online dapat dilakukan dengan menggunakan aplikasi tambahan sebagai media pembelajaran bagi dosen dan guru untuk melakukan interaksi kegiatan pembelajaran secara online. (Wijaya Indra, 2016) dalam penelitiannya menyebutkan bahwa penggunaan media lain berupa aplikasi pembelajaran dapat mendukung pembelajaran secara mandiri siswa. Senada dengan yang disampaikan oleh (Veri et al., 2019) bahwa adanya modul interaktif dalam bentuk mobile learning memudahkan siswa dalam mengakses materi belajar serta berdiskusi dalam pembahasan materi belajar dengan rekan siswa dan guru, dikarenakan adanya menu untuk diskusi dalam aplikasi mobile learning tersebut. (Firmansyah, 2021) mengungkapkan dalam hasil penelitiannya yang menyebutkan bahwa pembelajaran online memiliki keunggulan diantaranya yaitu meningkatkan kemandirian belajar siswa, pembelajaran dapat dilakukan dimana saja selama terkoneksi dengan internet dan memiliki materi yang luas. Didukung oleh pengertian dari pembelajaran online yang dikemukakan oleh (Riyana, C., \& Pd, n.d.) bahwa pembelajaran online tidak hanya berbicara tentang perangkat keras saja, akan tetapi meliputi pearngkat lunak yang dapat digunakan untuk mengirim data dan disimpan, kemudian dapat diakses kapan saja. Pembelajaran online yang dianjurkan oleh pemerintah merupakan salah satu upaya yang juga diberlakukan oleh Negara - Negara lain di dunia, dengan harapan adanya keberlangsungan pembelajaran dan pendidikan di setiap tingkat pendidikan selama masa pandemi Covid 19. Dengan diterapkannya pembelajaran online diharapkan pembelajaran berjalan secara efektif sehingga tercapai tujuan pembelajaran yang telah ditetapkan oleh praktisi pendidikan. Didukung oleh penelitian yang dilakukan oleh (Darmalaksana, W., Hambali, R., Masrur, A., \& Muhlas, n.d.) yang menyimpulkan bahwa pembelajaran secara online terbukti efektif dilaksanakan pada masa pandemik Covid 19.

(Sudiana, 2016) dalam penelitiannya menyebutkan bahwa penggunaan Learning Managements System (LMS) berupa aplikasi edmodo, schoology, geschool, dan Learnboost dan Medidu sebagai sarana pembelajaran secara online memiliki tingkat efektivitas yang sama dalam aktivitas belajar siswa. (Sefriani et al., 2021) dalam hasil penelitiannya menyebutkan bahwa penggunaan aplikasi edmodo dalam pembelajaran secara online efektif meningkatkan hasil belajar statistika mahasiswa. (Wijaya \& Sefriani, 2020) mengungkapkan dalam penelitiannya bahwa penggunaan media pembelajaran dalam bentuk aplikasi perangkat lunak efektif digunakan pada saat pembelajaran. Senada dengan yang disampaikan oleh Sefriani, (Sefriani, R., Wijaya, I., \& Radyuli, 2018) bahwa media pembelajaran yang dikembangkan dalam bentuk aplikasi berbasis mobile sangat efektif mendukung pembelajaran. LMS merupakan suatu aplikasi yang bersifat open source yang dapat digunakan oleh siapa saja dalam kegiatan belajar mengajar secara online. Beberapa aplikasi LMS yang tidak berbayar diantaranya edmodo, schoology, Geschool dll. Pada penelitian ini LMS yang digunakan dalam pembelajaran secara online pada perkuliahann fisika terapan. Pemanfaatan aplikasi edmodo membantu mahasiswa untuk mengakses tugas, materi ajar serta latihan yang diberikan oleh dosen 
4733 Efektivitas Pembelajaran Online di Masa Pandemi Covid-19 - Rini Sefriani, Rina Sepriana, Indra Wijaya, Menrisal

DOI: https://doi.org/10.31004/edukatif.v3i6.1430

pengampu mata kuliah di masa pandemic covid 19. Alamat situs edmodo yang bisa dikunjungi oleh siapapun yaitu https://new.edmodo.com. Dosen dan mahasiswa mengunjungi alamat situs tersebut kemudian memilih sesuai dengan perannya. (Ahangari \& Babapour, 2015) menyebutkan dalam penelitiannya bahwa edmodo efektif digunakan dalam pembelajaran. (Susanti \& Effendi, 2020) menyimpulkan dalam penelitiannya bahwa edmodo efektif meningkatkan minat belajar siswa. (Fembriani, F., Koroh, T. R., Pasmiyati, P., \& Polin, n.d.) mengungkapkan bahwa edmodo efektif meningkatkan hasil belajar mahasiswa dengan kategori sedang. (Zainudin, Z., \& Pambudi, n.d.) menyebutkan dalam penelitiannya bahwa penerapan perangkat pembelajaran fisika dasar berbasis keterampilan berpikir kritis dengan menggunakan aplikasi edmodo platform android efektif meningkatkan kemampuan berpikir kritis siswa dan respon positif siswa terhadap pembelajaran. Didukung oleh penelitian (Sefriani \& Sepriana, 2020) bahwa penggunaan LMS dalam perkuliahan online membantu dosen dan mahasiswa dalam berinteraksi dan berdiskusi terkait materi pembelajaran. (Wijaya, I., \& Arsyah, n.d.) dalam penelitiannya juga menyebutkan bahwa aplikasi edmodo berpengaruh meningkatkan hasil belajar siswa. Maka dalam penelitian ini mengungkapkan besar efektivitas aplikasi edmodo sebagai LMS dalam perkuliahan fisika terapan dalam pembelajaran online di masa pandemik Covid-19.

\section{METODE PENELITIAN}

Jenis penelitian ini adalah penelitian eksperimen semu, dengan desain penelitian pre-test dan post-test. Penelitian ini bertujuan untuk mengungkapkan seberapa efektif penggunaan aplikasi LMS edmodo dalam pembelajaran online pada mahasiswa jurusan Pendidikan Teknik Informatika pada mata kuliah Fisika Terapan pada masa pandemi COVID-19. Pre-test dan post-test diberikan kepada mahasiswa untuk mengetahui perbedaan nilai antara pre-test dan hasil post-test pembelajaran online. Kemudian, hasil pre-test dan post-test dibandingkan sehingga terdapat perbedaan antara keduanya. Berikut desain penelitian"one group pretestposttest design" dapat dilihat pada gambar 1 berikut;

$$
\text { O1 } \quad \mathrm{X}
$$

\section{Gambar 1. One -group pretest-posttest design ( dantes, 2017)}

O1 adalah nilai pretest sebelum menggunakan aplikasi edmodo, $\mathrm{X}$ adalah perlakuan perkuliahann yang diterapkan, $\mathrm{O} 2$ adalah nilai posttest setelah menggunakan aplikasi edmodo pada perkuliahan fisika terapan. Rancangan kegiatan perkuliahan fisika terapan dengan menggunakan aplikasi edmodo.

Tabel 1. Perbedaan perlakuan pembelajaran pretes dan posttest

\begin{tabular}{|c|c|c|}
\hline Pretest & Perlakuan & Posttest \\
\hline $\begin{array}{l}\text { Nilai sebelum menggunakan } \\
\text { aplikasi edmodo pada perkuliahan } \\
\text { fisika terapan }\end{array}$ & $\begin{array}{l}\text { Penggunaan aplikasi edmodo } \\
\text { dalam perkuliahan fisika terapan }\end{array}$ & $\begin{array}{l}\text { Nilai setelah menerapkan } \\
\text { penggunaan edmodo dalam } \\
\text { perkuliahan fisika terapan }\end{array}$ \\
\hline
\end{tabular}

Nilai Sebelum menggunakan aplikasi edmodo dikategorikan sebagai pretest, sementara perlakuan diterapkan menggunakan aplikasi edmodo diperoleh nilai rata-rata micro teaching setelah penerapannya, maka ini termasuk kategori posttest.

\section{Subjek penelitian}

Subjek penelitian ini adalah mahasiswa jurusan pendidikan teknik informatika yang terdaftar pada perkuliahan fisika terapan yang menerapkan perkuliahan dengan menggunakan aplikasi edmodo. Teknik sampling yang digunakan yaitu dengan teknik sampling purposive, maka jumlah sampel pada penelitian ini 
4734 Efektivitas Pembelajaran Online di Masa Pandemi Covid-19 - Rini Sefriani, Rina Sepriana, Indra Wijaya, Menrisal

DOI: https://doi.org/10.31004/edukatif.v3i6.1430

adalah sebanyak 33 orang. Pengumpulan data dilakukan dengan menggunakan instrument berupa soal tes pemahaman terkait materi rangkaian listrik, dan medan magnet yang harus dikuasi oleh mahasiswa.

2. Perhitungan efektivitas penggunaan edmodo

Menurut ( Hake dalam Sundayana, 2014 : h. 151) "Uji Normalitas Gain adalah sebuah uji yang bisa memberikan gambaran umum peningkatan skor hasil pembelajaran antara sebelum dan sesudah diterapkannya suatu perlakuan". Adapun rumus uji N-Gain adalah:

$$
\text { Normalized Gain }(g)=\frac{\text { Posttest Score }- \text { Pretest Score }}{\text { Maximum Score-Pretest Score }}
$$

Sedangkan untuk kategorinya kita bisa menggunakan interpretasi indeks Gain ternormalisasi (g) menurut Hake yang sudah dimodifikasi :

Tabel 2. Interpretasi index N-Gain

\begin{tabular}{|c|c|}
\hline N-GainScore $(\mathbf{g})$ & Interpretasi \\
\hline$-1.00<\mathrm{g}<0,0$ & Decrease \\
\hline $\mathrm{g}=0,0$ & Stable \\
\hline $0,0<\mathrm{g}<0,30$ & Low \\
\hline $0,30<\mathrm{g}<0.70$ & Average \\
\hline $0.70<\mathrm{g}<1.00$ & High \\
\hline
\end{tabular}

Sumber : Hake dalam Sundayana $(2014$, h.15I)

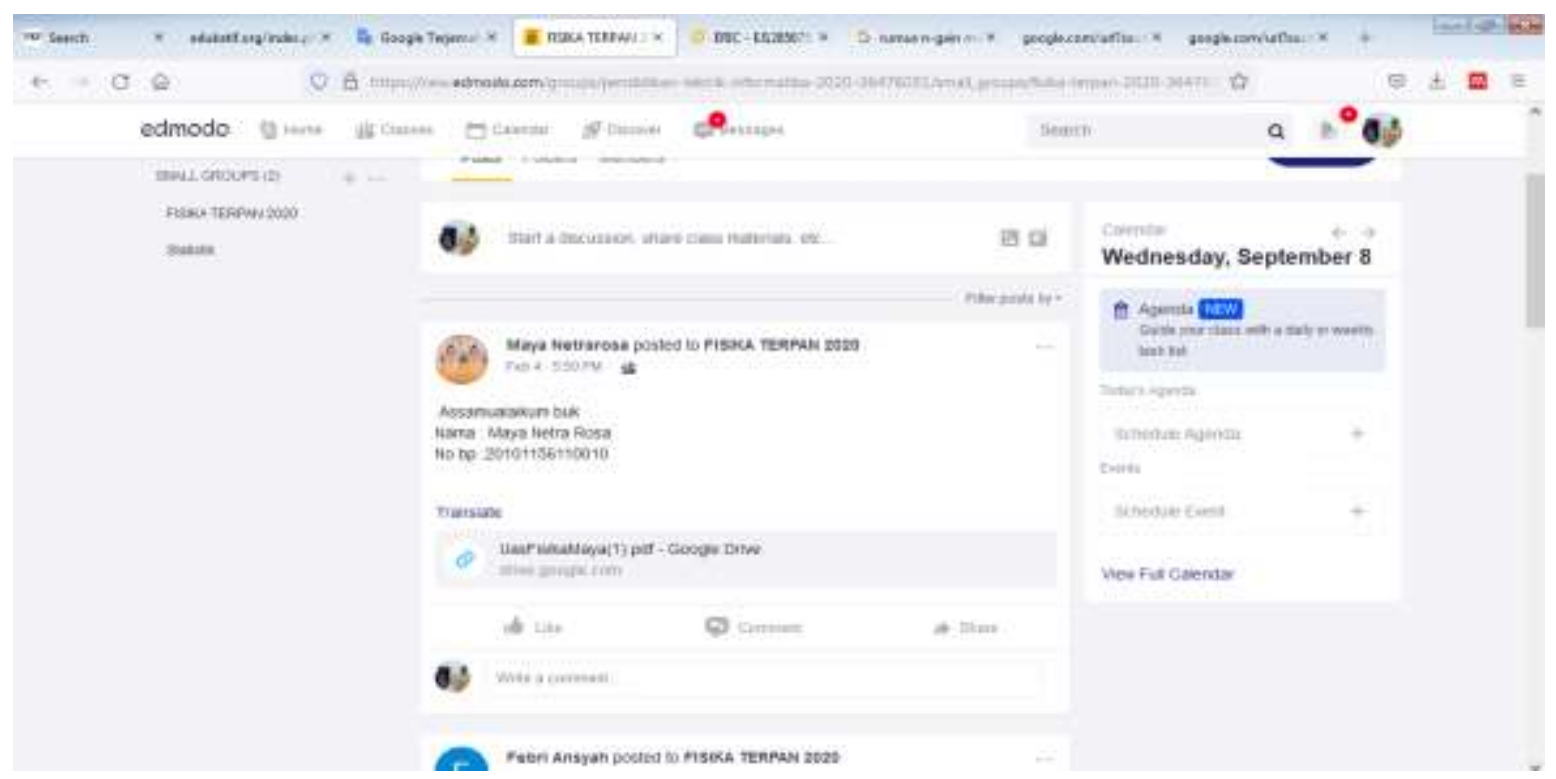

Gambar 2. Perkuliahan Fisika Terapan dengan menggunakan aplikasi Edmodo 
4735 Efektivitas Pembelajaran Online di Masa Pandemi Covid-19 - Rini Sefriani, Rina Sepriana, Indra Wijaya, Menrisal

DOI: https://doi.org/10.31004/edukatif.v3i6.1430

\section{HASIL DAN PEMBAHASAN PENELITIAN}

Pemanfaatan platform learning management system (LMS) edmodo sangat membantu dosen dan mahasiswa dalam perkuliahan fisika terapan dalam melakukan interaksi, berdiskusi serta mengajukan pertanyaan kepada dosen. Hal ini didukung oleh menu-menu yang tersedia dalam aplikasi edmodo. kemudahan dan kepraktisan dari aplikasi edmodo membuat pembelajaran fisika terapan secara online dapat dioptimalkan penggunaannya. Berikut rata-rata nilai fisika terapan sebelum dan sesudah menggunakan aplikasi LMS edmodo.

Tabel 3. Nilai rata-rata fisika terapan

\begin{tabular}{ll|r|r|r|r|r|r}
\hline & $\mathrm{N}$ & Minimum & Maximum & Sum & Mean & Std. Deviation & \multicolumn{1}{|c|}{ Variance } \\
\hline pre_test & 33 & 35.00 & 78.00 & 2025.00 & 61.3636 & 10.25554 & 105.176 \\
\hline post_test & 33 & 50.00 & 90.00 & 2263.00 & 68.5758 & 6.92834 & 48.002 \\
\hline Valid N & 33 & & & & & & \\
\hline
\end{tabular}

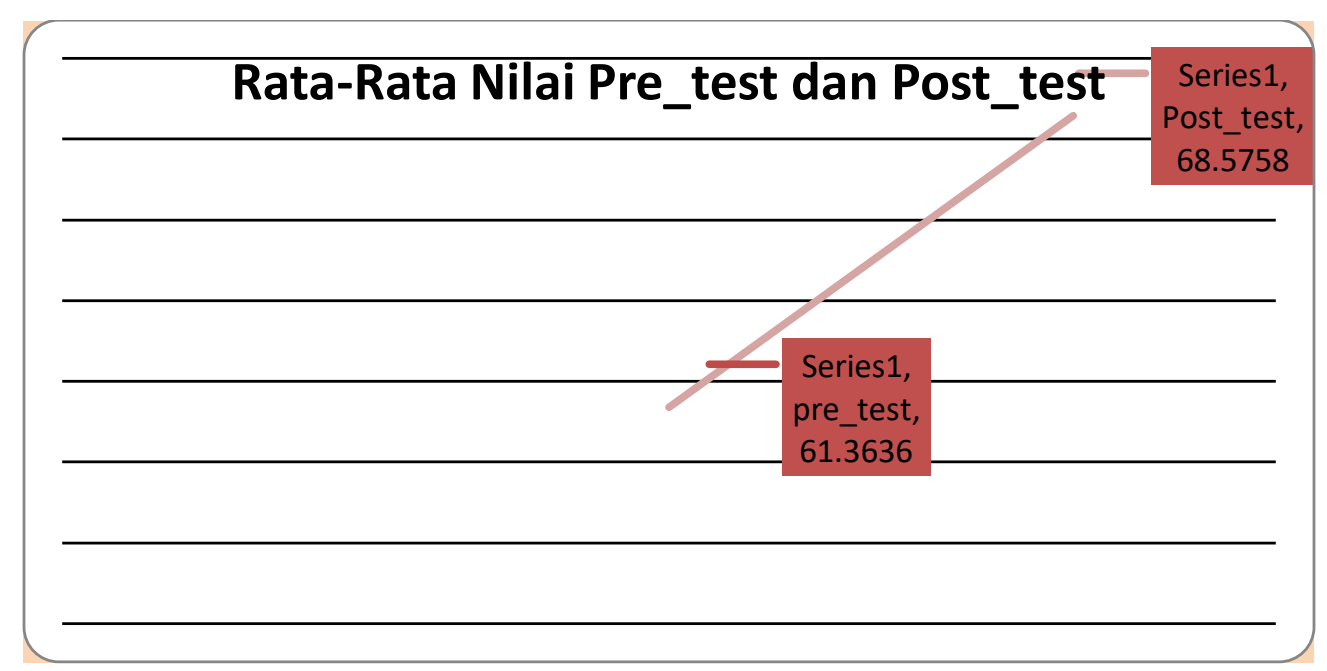

Gambar 3. Rata-rata Nilai Pre-Test dan Post-Test Fisika Terapan

Untuk mengetahui tingkat efektivitas penggunaan aplikasi edmodo, maka dapat dlihat pada perhitungan berikut :

\begin{tabular}{lll}
\hline N-Gain $=$ & \multicolumn{6}{c}{$68,57-61.36$} \\
\cline { 2 - 2 } & $90-61,36$ & $=0,25$ \\
\hline
\end{tabular}

Berdasarkan perhitungan nilai uji N-Gain di atas dapat dilhat bahwa nilai efektivitas penggunaan aplikasi edmodo pada pembelajaran fisika terapan secara online diperoleh sebesar 0,25 dengan interpretasi tingkat keefektifan yang rendah, akan tetapi aplikasi edmodo cukup efektif digunakan dalam pembelajaran online pada mata kuliah fisika terapan oleh mahasiswa jurusan pendidikan teknik informatika. (Susilawati et al., 2020) dalam penelitiannya juga menemukan adanya peningkatan hasil belajar dengan menggunakan aplikasi edmodo pada siswa. Didukung oleh penelitian yang dilakukan (Yunita, 2016) yang menyebutkan bahwa hasil belajar fisika siswa menjadi lebih baik setelah diterapkannya aplikasi edmodo dalam pembelajaran fisika. (Warjanto \& Azhar, 2014) dalam penelitiannya menngungkapkan bahwa penggunaan edmodo berhasil meningkatkan hasil belajar siswa. (Ompusunggu \& Sari, 2019) juga menyebutkan bahwa aplikasi edmodo merupakan salah satu alternative LMS yang dapat dimanfaatkan oleh para pendidik dalam pembelajaran sehingga diasumsikan hasil belajar siswa meningkat. Hal ini menunjukkan bahwa penggunaan 
4736 Efektivitas Pembelajaran Online di Masa Pandemi Covid-19 - Rini Sefriani, Rina Sepriana, Indra Wijaya, Menrisal

DOI: https://doi.org/10.31004/edukatif.v3i6.1430

aplikasi edmodo dalam pembelajaran efektif meningkatkan hasil belajar, dikarenakan adanya pembangunan belajar mandiri dalam aplikasi tersebut, serta diskusi yang dapat dipantau oleh guru di berbagai tempat dan waktu. (Sefriani et al., 2021) dalam penelitiannya juga menunjukkan adanya peningkatan nilai siswa dengan menggunakan aplikasi LMS Edmodo.

\section{KESIMPULAN}

Penelitian ini menyimpulkan bahwa pembelajaran online yang dilakukan pada masa pandemik Covid-19 sangat memungkinkan untuk dapat memanfaatkan aplikasi LMS yang bersifat open source, sehingga dapat digunakan oleh siapapun dalam kegiatan belajar mengajar. LMS edmodo adalah salah satu yang telah berhasil digunakan dalam pembelajaran online selama masa pandemik Covid 19, yang ditunjukkan dengan hasil belajar yang lebih baik diperoleh oleh mahasiswa setelah menerapkan aplikasi edmodo dalam pembelajaran. Ini di dukung oleh penelitian (Yunita, 2016) yang mengungkapkan hasil belajar fisika siswa meningkat setelah penggunaan aplikasi edmodo dalam kegiatan pembelajaran. Didukung juga oleh penelitian (Evin Yudhi Setyono, 2013) yang menyebutkan bahwa setelah menggunakan Edmodo berpengaruh secara signifikan terhadap hasil belajar siswa. hal yang sama juga diungkapkan oleh (Rosyidah et al., 2018), bahwa penggunaan Edmodo berpengaruh dalam peningkatan hasil belajar siswa.

\section{UCAPAN TERIMA KASIH}

Ucapan terima kasih kami sampaikan kepada Dekan Fakultas Keguruan dan Ilmu Pendidikan yang terus mendorong para dosen untuk melakukan penelitian dan menghasilkan publikasi ilmiah. Ketua Lembaga Penelitian dan Pengabdian Kepada Masyarakat UPI YPTK Padang, para dosen dan mahasiswa Jurusan Pendidikan Teknik Informatika FKIP UPI YPTK Padang yang sudah berkontribusi dalam penyelesaian penelitian, serta semua pihak yang sudah mendoakan selesainya artikel ini.

\section{DAFTAR PUSTAKA}

Ahangari, S., \& Babapour, M. (2015). The Effect Of Self-Correction And Peer- Correction On Efl Learners' Writing. Modern Journal Of Language Teaching Methods, 5(2), 465-473. Http://Www.Ijeionline.Com/Attachments/Article/36/Ijeionline_Vol.2_No.2_2015-2-08.Pdf

Darmalaksana, W., Hambali, R., Masrur, A., \& Muhlas, M. (N.D.). Analisis Pembelajaran Online Masa Wfh Pandemic Covid-19 Sebagai Tantangan Pemimpin Digital Abad 21. Karya Tulis Ilmiah (Kti) Masa Work From Home (Wfh) Covid-19 Uin Sunan Gunung Djati Bandung, 1-12.

Evin Yudhi Setyono. (2013). Pengaruh Penggunaan Media Jejaring Sosial Edmodo Terhadap Hasil Belajar Mahasiswa Pada Topik Pembuatan Kurva-S Menggunakan Microsoft Excell. Soshum Jurnal Sosial Dan Humaniora, 3(1), 69-76. Http://Ojs.Pnb.Ac.Id/Index.Php/Soshum/Article/Download/226/194

Fembriani, F., Koroh, T. R., Pasmiyati, P., \& Polin, R. (N.D.). Efektivitas Edmodo Terhadap Hasil Belajar Mahasiswa Pgsd Universitas Nusa Cendana. Jurnal Ilmiah Kontekstual,2((01),), 8-14.

Firman, F., \& Rahayu, S. (N.D.). Pembelajaran Online Di Tengah Pandemi Covid-19. Indonesian Journal Of Educational Science (Ijes),2((2),), 81-89.

Firmansyah, F. (2021). Motivasi Belajar Dan Respon Siswa Terhadap Online Learning Sebagai Strategi Pembelajaran Di Masa Pandemi Covid-19. Edukatif: Jurnal Ilmu Pendidikan, 3(2), 589-597. Https://Doi.Org/10.31004/Edukatif.V3i2.355

Ompusunggu, V. D. K., \& Sari, N. (2019). Efektifitas Penggunaan E-Learning Berbasis Edmodo Terhadap Kemampuan Komunikasi Matematika. Jurnal Curere, 3(2), 58-66. 
4737 Efektivitas Pembelajaran Online di Masa Pandemi Covid-19 - Rini Sefriani, Rina Sepriana, Indra Wijaya, Menrisal

DOI: https://doi.org/10.31004/edukatif.v3i6.1430

Https://Doi.Org/10.36764/Jc.V3i2.250

Riyana, C., \& Pd, M. (2020). (N.D.). Konsep Pembelajaran Online. Modul Pembelajaran On-Line, 1.

Rosyidah, Kartini, T., \& Kantun, S. (2018). Penggunaan Media Edmodo Untuk Meningkatkan Motivasi Dan Hasil Belajar Siswa. Jurnal Pendidikan Ekonomi, 13(2), $78-84$. Https://Doi.Org/10.19184/Jpe.V13i2.10878

Sefriani, R., Wijaya, I., \& Radyuli, P. (2018). Development Of Android Based Learning Media On The Subjects Of Digital Photo Composition For Vocational High School Student. Volt: Jurnal Ilmiah Pendidikan Teknik Elektro, 3(2).

Sefriani, R., \& Sepriana, R. (2020). Pengembangan Media E-Learning Berbasis Schoology Pada Pembelajaran Kurikulum Pendidikan Teknologi Dan Kejuruan. Edukatif: Jurnal Ilmu Pendidikan, 2(1), 8-14.

Sefriani, R., Sepriana, R., Wijaya, I., Radyuli, P., \& Menrisal. (2021). Blended Learning With Edmodo: The Effectiveness Of Statistical Learning During The Covid-19 Pandemic. International Journal Of Evaluation And Research In Education. Https://Doi.Org/10.11591/Ijere.V10i1.20826

Sudiana, R. (2016). Efektifitas Penggunaan Learning Management System Berbasis Online. Jppm (Jurnal Penelitian Dan Pembelajaran Matematika),9(2), 201-209.

Susanti, R. D., \& Effendi, M. M. (2020). Efektivitas Penggunaan Edmodo Dalam Pelaksanaan Ulangan Harian Matematika. Fibonacci Jurnal Pendidikan Matematika Dan Matematika, 6(1), 9-16. Efektivitas, Edmodo, Ulangan Harian.

Susilawati, S., Yasin, A. F., \& Chakim, A. (2020). Encouraging Learning Quality. 24(06), 9638-9645. Http://Repository.Uin-Malang.Ac.Id/5590/1/Pr260959.Pdf

Veri, J., Sefriani, R., Aulia, L., Keguruan, F., Putra, U., \& Yptk, I. (2019). Pengembangan Mobile Learning Berbasis Client Server Pada Mata Pelajaran Simulasi Digital. 5(3), 61-71.

Warjanto, S., \& Azhar, A. (2014). Pf-44: Efektifitas Social Learning Network Berbasis Edmodo Terhadap Hasil Belajar Siswa Sma Pada Materi Alat Optik. Prosiding Seminar Nasional Fisika, 3, 148-150.

Wijaya, I., \& Arsyah, R. H. (N.D.). Pengaruh Pembelajaran E-Learning Berbasis Edmodo Terhadap Hasil Belajar Simulasi Digital Kelas X Smk Negeri 9 Padang (Studi Kasus Jurusan Akomodasi Perhotelan). Majalah Ilmiah Upi Yptk, 22(1)., 22(1).

Wijaya, I., \& Sefriani, R. (2020). Development Of Interactive Media Based In Adobe. 5(3), 134-142. Https://Doi.Org/10.22216/Jcc.2020.V5i3.1982

Wijaya Indra, S. R. (2016). Interactive Multimedia Cd Design Chemistry Lesson In Concept Training Material And Amendment For Class X Vocational High School (Smk). Journal Of Dynamics, 1(1). Http://Ejournal.Kopertis10.Or.Id/Index.Php/Dynamics/Article/View/934

Yunita, L. (2016). Efektifitas Problem Based Learning Berbantuan Edmodo Untuk Meningkatkan Prestasi Belajar Fisika Studi Pada Suhu Dan Kalor Kelas X Teknik Kendaraan Ringan Smk Tunas Bangsa Wanareja. Prosiding Seminar Nasional Xi "Rekayasa Teknologi Industri Dan Informasi 2016 Sekolah Tinggi Teknologi Nasional Yogyakarta," 159-165.

Zainudin, Z., \& Pambudi, B. (N.D.). Efektivitas Penerapan Perangkat Pembelajaran Fisika Dasar Berbasis Keterampilan Berpikir Kritis Menggunakan Aplikasi Edmodo Berplatform Android. Prisma Sains: Jurnal Pengkajian Ilmu Dan Pembelajaran Matematika Dan Ipa Ikip Mataram,7((1),), 17-26. 